\title{
Development of methods for standardization of the active substance, namely the model mixture based on decamethoxine and thiotriazoline
}

\author{
L. I. Kucherenko ${ }^{\star 1,2, F}$, 0. O. Chonka ${ }^{1, C, D}$, 0. O. Portna ${ }^{1, B}$ \\ ${ }^{1}$ Zaporizhzhia State Medical University, Ukraine, ${ }^{2}$ SPA “Farmatron”, Zaporizhzhia, Ukraine
}

A - research concept and design; B - collection and/or assembly of data; C - data analysis and interpretation; D - writing the article;

$\mathrm{E}$ - critical revision of the article; $\mathrm{F}$ - final approval of the article

Today, the important problem is the creation of new decamethoxine and thiotriazoline based drugs for the treatment of stomatitis.

The aim of the work is to develop a method for quantitative determination of decamethoxine and thiotriazoline in the model mixture $(1: 25)$ by spectrophotometry.

Materials and methods. Series 6 model mixtures were made at the ratio of decamethoxine and thiotriazoline 1:25. We used certified substances: thiotriazoline series GTT 3460911 (manufacturer: State Enterprise Chemical Reagents Plant, Kharkiv), decamethoxine series № 010915 (manufacturer: LLC “PHARMCHIM”). Optizen POP spectrophotometer, polyvinyl alcohol, hydrochloric acid, and eosin were used.

Results. A method for quantitative determination of decamethoxine and thiotriazoline in MS was developed. It was established that the content of active substances in MS is thiotriazoline from 0.5021 to 0.5096 , decamethoxine from 0.0207 to 0.0211 .

Conclusions. A method for quantitative determination of decamethoxine and thiotriazoline in MS has been developed. The method of quantitative determination of decamethoxine and thiotriazoline in MS is reproducible.
Key words: decamethoxine, thiotriazoline, model mixtures, spectrophotometry.

\section{Zaporozhye} medical journal 2021; $23(5), 703-707$

*E-mail:

farm chem@bigmir.net

\section{Розроблення методики стандартизації діючих речовин у модельній суміші на основі декаметоксину та тіотріазоліну}

\section{А. І. Кучеренко, О. О. Чонка, О. О. Портна}

Створення нових лікарських засобів для лікування стоматиту на основі декаметоксину та тіотріазоліну - актуальна проблема.

Мета роботи - розроблення методики кількісного визначення декаметоксину та тіотріазоліну в модельній суміші $(1: 25)$ методом спектрофотометрії.

Матеріали та методи. Використали 6 серій модельних сумішей (MC), тіотріазолін серії GTT 3460911 (виробник ДП «Завод хімічних реактивів» НТК ІМК НАН УКРАЇНИ», м. Харків), декаметоксин серії № 010915 (виробник TOB «ФАРМХІМ», м. Шостка). Дослідження виконали, застосувавши спектрофотометр Optizen POP, полівініловий спирт, соляну кислоту, еозин.

Результати. Розробили методику кількісного визначення декаметоксину та тіотріазоліну в модельній суміші. Встановили, що вміст діючих речовин у МС становить: тіотріазоліну - 0,5021-0,5096, декаметоксину -0,0207-0,0211.

Висновки. Розроблено методику кількісного визначення декаметоксину та тіотріазоліну в МС. Метод кількісного визначення декаметоксину та тіотріазоліну в модельній суміші є відтворюваним.

\section{Разработка методики стандартизации действующих веществ в модельной смеси на основе декаметоксина и тиотриазолина}

\section{А. И. Кучеренко, Е. О. Чонка, Е. А. Портная}

Создание новых лекарственных средств для лечения стоматита на основе декаметоксина и тиотриазолина - актуальная проблема.

Цель работы - разработка методики количественного определения декаметоксина и тиотриазолина в модельной смеси (1:25) методом спектрофотометрии.

Материалы и методы. Использовали 6 серий модельных смесей (МС) тиотриазолина серии ПТТ 3460911 (производитель - ГП «Завод химических реактивов» НТК ИМК НАН Украины, г. Харьков), декаметоксин серии № 010915 (производитель -ООО «ФАРМХИМ», г. Шостка). В ходе исследования применили спектрофотометр Optizen POР, поливиниловый спирт, соляную кислоту, эозин.

Результаты. Разработали методику количественного определения декаметоксина и тиотриазолина в МС. Установлено, что содержание действующих веществ в модельной смеси составляет: тиотриазолина -0,5021-0,5096, декаметоксина 0,0207-0,0211.

Выводы. Разработана методика количественного определения декаметоксина и тиотриазолина в МС. Метод количественного определения декаметоксина и тиотриазолина в модельной смеси воспроизводим.
Киючові слова: Аекаметоксин, тіотріазолін, модельні суміші, спектрофотометрія.

Запорізький медичний журнал. 2021. T. 23, № 5(128). C. $703-707$

Киючевые слова: Аекаметоксин, тиотриазолин, модельные смеси, спектрофотометрия.

\section{Запорожский}

медицинский журнал 2021. T. 23, № 5(128). C. 703-707 
Over the past decade, considerable attention has been paid to the problem of prevention and treatment of chronic diseases of the oral mucosa.

This is primarily due to the increase in the number of patients who seek dental care for diseases of the oral mucosa (DOOM) [6].

At the same time, the similarity of the clinical manifestations of diseases of various etiology and pathogenesis in the oral cavity determines the difficulties in making the final diagnosis. The study of combined lesions of the skin, internal organs, oral mucosa, their relationship with general pathology is necessary for the doctor for the correct diagnosis. There is a relationship of most of the pathological processes occurring in various organs and systems of the body and their manifestations on the oral mucous membrane and the red border of the lips; therefore, it is lesions of the oral mucosa that are often the first signs of metabolic disorders, as well as various general somatic diseases, which in turn complicate the selection of drugs for treating these pathologies [3,13].

Today, the pharmaceutical market of Ukraine mainly offers foreign drugs, and they work in the narrow specifics of eliminating only symptoms, and not the pathogenesis of these diseases. That's why a very important problem is the creation of a new drug, which is not unique and can enrich the range at the domestic pharmaceutical market.

To create a new drug substance, the model mixture had to go through a series of studies. We have previously studied the formation of intermolecular complexes between these ingredients of the model mixture and conducted research of acute toxicity. According to the earlier studied data, we concluded that the model mixture belonged to a relatively harmless compound (class 4 ) and the joint combination of these drugs was not complicated by the formation of insoluble complexes.

In the development of a potential new drug, one of the criteria is quality. We have developed a method for standardizing a model mixture of thiotriazoline and decamethoxine [10-12]. The uniqueness of this method is that thiatriazoline and decamethoxine in their combined presence have not been previously determined and this is a new original study to determine the individual ingredients in the compatible composition.

It is known that the gold standard is the HPLC-DMD method, as this method is considered one of the most accurate. But due to its scarce availability, this method is financially costly in terms of equipment, and not all laboratories can handle them. Our goal was to use a spectrophotometer method to determine this combination.

\section{Aim}

The aim of the work is to develop a method for the quantitative determination of decamethoxine and thiotriazoline in a model mixture $(1: 25)$ by the spectrophotometry method.

\section{Materials and methods}

Series 6 model mixtures were made in the ratio of decamethoxine and thiotriazoline 1:25.
We use a certified substance: thiotriazoline series GTT 3460911 (manufacturer: State Enterprise Chemical Reagents Plant, Kharkiv), decamethoxine series № 010915 (manufacturer: LLC "PHARMCHIM").

The following devices were used:

- single-beam Optizen POP spectrophotometer; its main metrological characteristics is measuring range $198-1100 \mathrm{~nm}$, its error +0.005 B (the ultimate manufacturer is South Korea);

- pipette dispenser with the following measurement limits: $100-1000 \mu \mathrm{l}, 20-200 \mu \mathrm{l}, 2-20 \mu \mathrm{l}$, its error $\pm 1.0 \%$, $\pm 1.5 \%, \pm 2.5 \%$, manufactured in Ukraine;

- laboratory electronic scales OHAUS PA 214C (accuracy class I special); its main metrological characteristics is measuring range $0.01-210.00 \mathrm{~g}$, their error $\pm 0.0002 \mathrm{~g}$ (manufactured in the USA).

Characteristics of excipients:

Polyvinyl alcohol: white powder, density 1.200-1.320. Soluble in water when heated. PVA film has grease resistance, gas permeability.

Hydrochloric acid: like other strong acids, it actively dissolves most metals with the release of hydrogen, interacts with metal oxides, and so on. Concentrated hydrochloric acid contains $37 \% \mathrm{HCl}$ and has a density of $1.19 \mathrm{~g} / \mathrm{cm}^{3}$. It has a pungent odor and "smokes" in the air due to the release of hydrogen chloride gas.

Eosin is a water-soluble xanthene dye obtained by the action of bromine on fluorescein. Intense pink color.

Purified water (Latin Aqua purificata) is regulated by the pharmacopoeia article FS.2.2.0020.15 (GF XIII edition), used for the production and dissolution of drugs, production of water for injections and testing of drugs.

The basis for the determination of thiotriazoline in the mixture was a modified spectrophotometric method for the analysis of the thiotriazoline substance. The studies were conducted using a spectrophotometer Optizen POP, measurements were performed at a wavelength in the range $200-270 \mathrm{~nm}$, the cell thickness is $10 \mathrm{~mm}$. The determination of decamethoxine in the mixture was taken a modified spectrophotometric method for the analysis of the substance with the addition of polyvinyl alcohol, eosin, and hydrochloric acid.

The studies were conducted using a spectrophotometer Optizen POP, measurements were performed at a wavelength in the range $400-600 \mathrm{~nm}$, the cell thickness of $10 \mathrm{~mm}$. The UV spectra of thiotriazoline or decamethoxine were recorded due to the presence of anotherAPI on the following parameters: the position of the maximum absorption band; the shape of the absorption line.

\section{Results}

The results show that this method, namely the spectrophotometric method, is correct and can be used in the future since thiotriazoline does not affect the determination of decamethoxine. Besides, this method allows seeing that the absorption spectrum of thiotriazoline does not affect the determination of decamethoxine [7,9].

The spectra of decamethoxine and thiotriazoline were recorded under various conditions.

The spectrum is presented in Fig. 1 and 2. 
As obvious from the figures, decamethoxine in the region of 200-270 nm actually was not absorbed and thiotriazoline in the area from 400 to $600 \mathrm{~nm}$ did not practically influence the research results, which gave us the opportunity to use both of them in combination.

Further, during spectrophotometric determination, a model mixture of decamethoxine and thiotriazoline (1:25) was analyzed [8].

Method for the quantitative determination of the model mixture

1.1 Determination of thiotriazoline in the model mixture

Preparation of the test solution (determination of thiotriazoline). $0.52 \mathrm{~g}$ (exact linkage) model mixture (where thiotriazoline is 0.5 and decamethoxine is 0.02 ) was placed in a volumetric flask of $50 \mathrm{ml}$ and diluted according to the developed method:

$5 \mathrm{ml}$ of the dilution was transferred to a $100 \mathrm{ml}$ flask; the volume was brought up to the mark with water; $10 \mathrm{ml}$ of this new dilution was transferred to a new bottle for further analysis. We added $2.0 \mathrm{ml}$ of $0.1 \mathrm{M}$ acidum chloricum, and $88 \mathrm{ml}$ of water and maintained it over an hour at a temperature of $20^{\circ} \mathrm{C}$.

1.2 Preparation of the working standard thiotriazoline sample

$0.5 \mathrm{~g}$ of thiotriazoline (accurately weighed) was placed in a $50 \mathrm{ml}$ volumetric flask, dissolved with water and the volume was brought up to the mark with water. and make made dilutions according to the developed method: $5 \mathrm{ml}$ are taken from the dilution and transferred to a $100 \mathrm{ml}$ flask, the volume is brought up to the mark with water. from this dilution was taken $10 \mathrm{ml}$ and transferred to a new bottle for further analysis. We added $2.0 \mathrm{ml}$ of $0.1 \mathrm{M}$ acidum chloricum, and $88 \mathrm{ml}$ of water and maintained in over an hour at a temperature of $20^{\circ} \mathrm{C}$.

The spectra of the investigated solution of thiotriazoline in the model mixture and the WSS of thiotriazoline are shown in Fig. 3 and 4.

The gram content of thiotriazoline was calculated using the formula:

$X=A x \cdot m o \cdot 50 \cdot 5 \cdot 100 \cdot 10 \cdot 100 \cdot B \cdot P A 0 \cdot m x$. $\cdot 50 \cdot 5 \cdot 100 \cdot 10 \cdot 100 \cdot 100=A x \cdot m o \cdot B \cdot P A 0 \cdot m x \cdot$ $\cdot 100 X=A x \cdot m o \cdot 50 \cdot 5 \cdot 100 \cdot 10 \cdot 100 \cdot B \cdot P A 0 \cdot m x \cdot$ $\cdot 50 \cdot 5 \cdot 100 \cdot 10 \cdot 100 \cdot 100=A x \cdot m o \cdot B \cdot P A 0 \cdot m x \cdot 100$

where $A_{x}$ - the optical density of the test substance;

$A_{0}$ - the optical density of the reference solution;

$m_{0}$ - weight of the standard sample;

$m_{x}$ - weight of the test sample;

$\mathrm{B}$ - average weight of thiotriazoline in the model mixture;

P - percentage content (WSS) thiotriazoline (99.9\%).

Account data are presented in Table 1.

1.3 Determination of decamethoxine in the model mixture

Preparation of the test solution of decamethoxine. $0.52 \mathrm{~g}$ (exact linkage) of model mixture (where there is 0.50 of thiotriazoline and 0.02 of decametoxine) was put in a $50 \mathrm{ml}$ volumetric flask, dissolved with water and the volume is adjusted to the mark. $10 \mathrm{ml}$ of this solution was transferred into a $100 \mathrm{ml}$ flask; $8 \mathrm{ml}$ of $0.1 \%$ alcohol polyvinyl, $1.5 \mathrm{~mL}, 0.05 \mathrm{M}$ solution acidum chloricum and 4

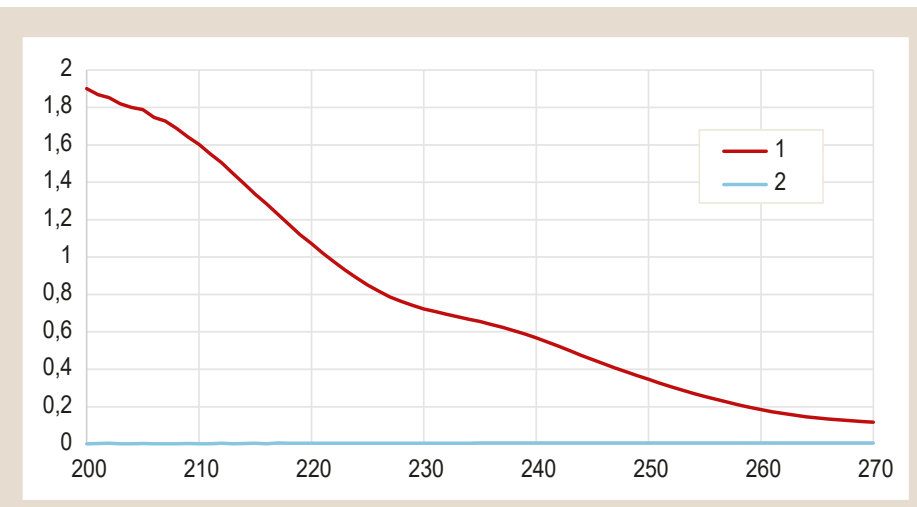

Fig. 1. UV spectra of thiotriazoline and decamethoxine under conditions for the determination of thiotriazoline. 1: decamethoxine; 2: thiotriazoline. The wavelength of thiotriazoline is $\Lambda=234 \mathrm{~nm}$.

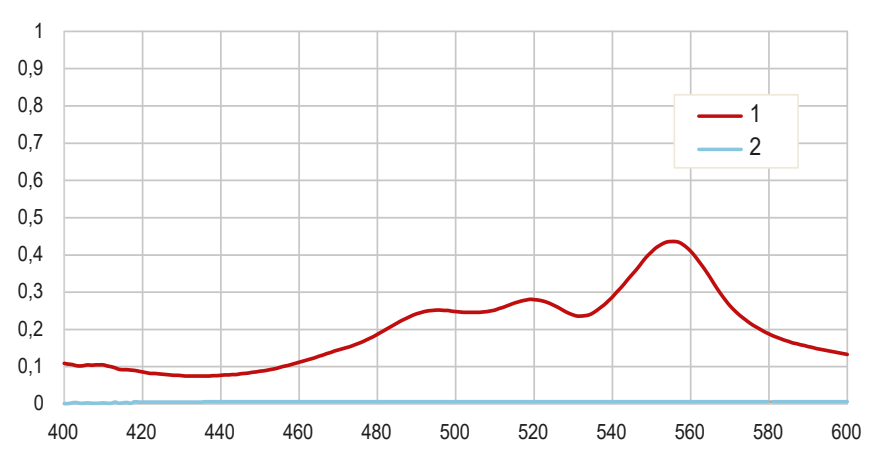

Fig. 2. UV spectra of thiotriazoline and decamethoxine under conditions for the determination of decamethoxine. 1: decamethoxine; 2: thiotriazoline. The wavelength of decamethoxine is $\Lambda=536 \mathrm{~nm}$.

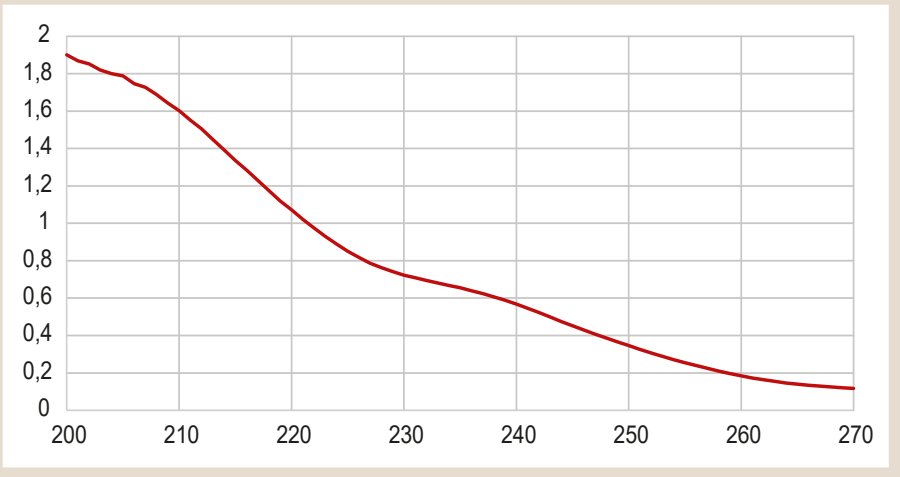

Fig. 3. The spectrum of determination of thiotriazoline in the model mixture. The wavelength of thiotriazoline is $\lambda=234 \mathrm{~nm}$.

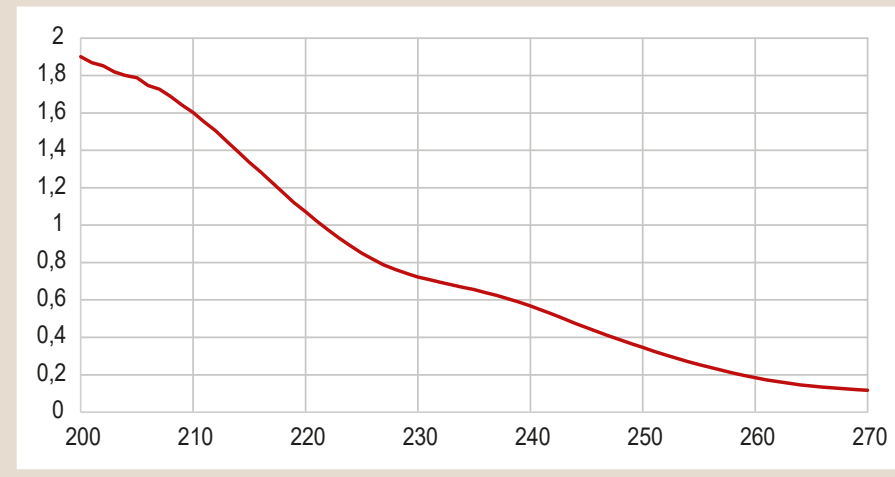

Fig. 4. Spectrum of the working standard sample of thiotriazoline. 
Table 1. The gram content of thiotriazoline in the model mixture series 1

\begin{tabular}{l|l|l|l|l}
$\begin{array}{l}\text { Series №TT0460919 } \\
\text { № }\end{array}$ & $\begin{array}{l}\text { Weight of } \\
\text { the mixture, g }\end{array}$ & $\begin{array}{l}\text { Absorption, } \\
\text { A }\end{array}$ & $\begin{array}{l}\text { Gram content } \\
\text { (thiotriazoline) }\end{array}$ & Statistics \\
\hline 1 & 0.5221 & 0.395 & 0.5096 & $\bar{x}=0.5212$ \\
2 & 0.5208 & 0.392 & 0.5074 & $\mathrm{~S}^{2}=0.00518$ \\
$\mathrm{~S}=0.0797$ \\
$\mathrm{X}(0.95)=0.0683$
\end{tabular}

Table 2. The gram content of decamethoxine in the model mixture of series 1

\begin{tabular}{l|l|l|l|l}
$\begin{array}{l}\text { Series №010915 } \\
\text { № }\end{array}$ & $\begin{array}{l}\text { Weight of } \\
\text { the mixture, }\end{array}$ & $\begin{array}{l}\text { Absorption, } \\
\text { A }\end{array}$ & $\begin{array}{l}\text { Gram conten } \\
\text { (decamethoxine) }\end{array}$ & Statistics \\
\hline 1 & 0.5216 & 0.534 & 0.0207 & $\overline{\mathrm{X}}=0.02105$ \\
2 & 0.5214 & 0.538 & 0.0210 & $\mathrm{~S}^{2}=0.00155$ \\
\hline 3 & 0.5212 & 0.535 & 0.0212 & $\mathrm{~S}=0.0393$ \\
\hline 4 & 0.5210 & 0.539 & 0.0212 & \\
\hline 5 & 0.5213 & 0.536 & 0.0211 & \\
6 & 0.5220 & 0.538 & 0.0211 & \\
\hline Sol. & WSS 0.0226 & 0.536 & & \\
\hline
\end{tabular}

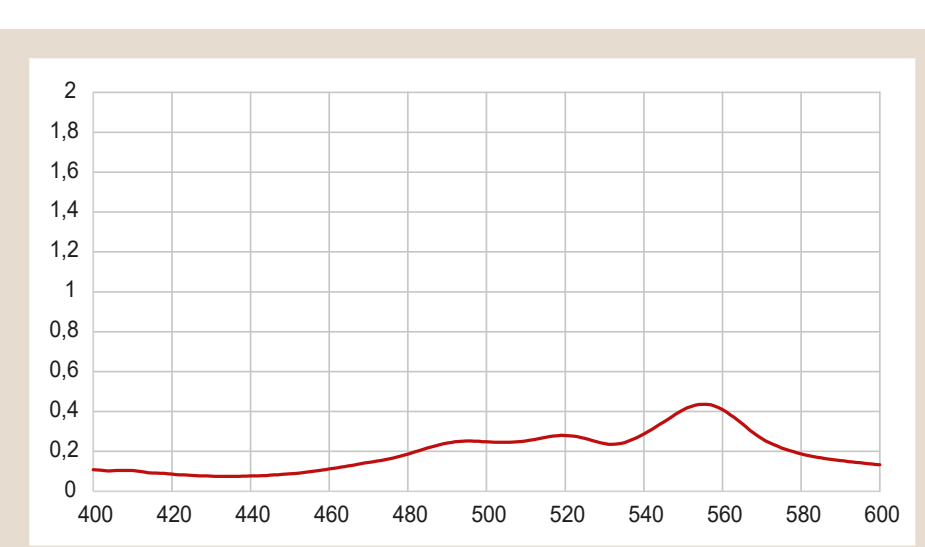

Fig. 5. The spectrum of determination of decamethoxine in the model mixture. The wavelength of decamethoxine is $\Lambda=556 \mathrm{~nm}$.

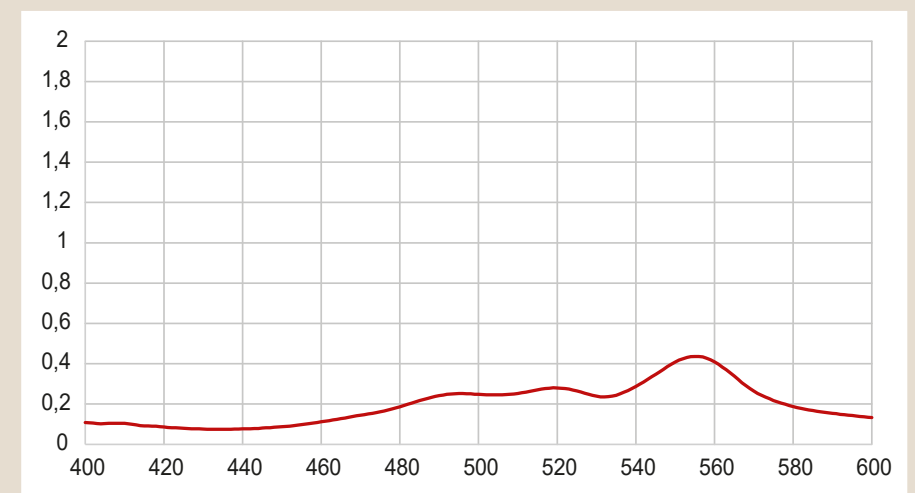

Fig. 6. WSS spectrum of decamethoxine.

$\mathrm{ml}$ of $0.07 \%$ solution of eosin were added, the volume was adjusted with water to the mark.

Preparation of decamethoxine operational standard. Accurately weighed $0.02 \mathrm{~g}$ of decamethoxine (exact weighed) was placed in a $50 \mathrm{ml}$ volumetric flask and the volume was adjusted with water to the mark. $10 \mathrm{ml}$ of this dilution was transferred into a $100 \mathrm{ml}$ flask, and $8 \mathrm{ml}$ of $0.1 \%$ alcohol polyvinyl, $1.5 \mathrm{~mL}, 0.05 \mathrm{M}$ solution acidum chloricum, and $4 \mathrm{ml}$ of $0.07 \%$ solution of eosin were added; volume was adjusted with water to the mark $[4,5]$.

The spectra are shown in Fig. 5 and 6.

The gram content of decamethoxine was calculated, according to the formula:

$X=A x \cdot m o \cdot 50 \cdot 10 \cdot 100 \cdot B \cdot P A 0 \cdot m x \cdot 50 \cdot 10$. $\cdot 100 \cdot 100=A x \cdot m o \cdot B \cdot P A 0 \cdot m x \cdot 100 X=A x \cdot m o$. $\cdot 50 \cdot 10 \cdot 100 \cdot \mathrm{B} \cdot \mathrm{PA} \cdot \mathrm{mx} \cdot 50 \cdot 10 \cdot 100 \cdot 100=\mathrm{Ax}$. mo $\cdot \mathrm{B} \cdot \mathrm{PAO} \cdot \mathrm{mx} \cdot 100$

where $A_{x}$ - the optical density of the test substance; $A_{0}$ - the optical density of the reference solution;

$m_{0}$ - weight of a sample of a standart sample;

$\mathrm{m}_{\mathrm{x}}$ - weight of the test sample;

$\mathrm{B}$ - average masa decamethoxine in model mixture;

$\mathrm{P}$ - percentage contain WSS decamethoxine $(99.9 \%)$.

The data on the gram content of decamethoxine in the model mixture are presented in Table 2.

\section{Discussions}

The possibility of using these active substances are the following. First of all, before using this combination, we required quantum chemical calculations and woodcut method. These studies have shown that there is no interaction between the ingredients Obtaining a tablet mass is possible at a temperature not exceeding $115^{\circ} \mathrm{C}$.

As seen from Table 1, the content of thiotriazoline in the model mixture was in the range from 0.5021 to 0.5096 . Thus, in terms of the content of the active substance, the investigated series of the model mixture meets the requirements of the State Pharmacopoeia.

The results presented in Table 2 were in the range from 0.0207 to 0.0211 , which corresponded to the requirements of the State Pharmacopoeia. We have studied other five series of model mixture which also meet pharmacopoeia requirements and analyzed existing content the substance where decamethoxine ranges from 0.0206 to 0.0214 , and thiotriazoline ranges from 0.5026 to 0.5116 . As can be seen from the data obtained, the developed standardization procedure for the active substances in the model mixture is reproducible [1,2].

\section{Conclusions}

1. It was found that decamethoxine practically does not absorb in the region from $200-270 \mathrm{~nm}$, and thiotriazoline in the region from $400-600 \mathrm{~nm}$ practically does not affect the results. This enables to determine decamethoxine in the presence of thiotriazoline and vice versa, in different conditions.

2. A method for the quantitative determination of decamethoxine and thiotriazoline in a model mixture has been developed.

3. The method for the quantitative determination of decamethoxine and thiotriazoline in the model mixture was reproducible.

Prospects for further research: in the future, the developed methodology can be used for pills standartization. 


\section{Funding}

The work is part of the joint integrated work of the Department of Pharmaceutical Chemistry of Zaporizhzhia State Medical University and NGO "Pharmatron".

Conflicts of interest: authors have no conflict of interest to declare. Конфмікт інтересів: віАсутній.

Надійшла до редакції / Received: 24.02.2021

Після Аоопрацювання / Revised: 01.04.2021

Прийнято Ао Аруку / Accepted: 07.04.2021

\section{Information about authors:}

Kucherenko L. I., PhD, DSc, Professor, Head of the Department of Pharmaceutical Chemistry, Zaporizhzhia State Medical University, Vice-President of SPA "Farmatron", Ukraine.

ORCID ID: 0000-0003-2229-0232

Chonka 0. 0., Postgraduate student of the Department of

Pharmaceutical Chemistry, Zaporizhzhia State Medical University, Ukraine.

ORCID ID: 0000-0002-6793-2668

Portna 0. O., PhD, Associate Professor of the Department of Pharmaceutical Chemistry, Zaporizhzhia State Medical University, Ukraine.

ORCID ID: 0000-0002-4752-1888

\section{Відомості про авторів:}

Кучеренко ^. І., А-р фарм. наук, професор,

зав. каф. фармацевтичної хімії, Запорізький державний медичний університет, віцепрезидент НВО «Фарматрон», м. Запоріжжя, Україна.

Чонка О. О., аспірантка каф. фармацевтичної хімії, Запорізький Аержавний медичний університет, Україна.

Портна О. О., канА. фарм. наук, Аоцент каф. фармацевтичної хімії, Запорізький Аержавний медичний університет, Україна.

\section{Сведения об авторах:}

Кучеренко А. И., А-р фарм. наук, профессор

зав. каф. фармацевтической химии, Запорожский государственный медицинский университет, вице-президент НПО "Фарматрон", г. Запорожье, Украина.

Чонка Е. О., аспирант каф. фармацевтической химии,

Запорожский госуАарственный меАицинский университет, Украина.

Портная Е. А., канА. фарм. наук, Аоцент каф. фармацевтической химии, Запорожский государственный медицинский университет, Украина.

\section{References}

[1] State Enterprise Ukrainian Scientific Pharmacopoeial Center of Medicines Quality. (2015). Derzhavna Farmakopeia Ukrainy [The State Pharmacopoeia of Ukraine] (2nd ed., Vol. 1). Kharkiv: Naukovo-ekspertnyi farmakopeinyi tsentr. [in Ukrainian].

[2] Grizodub, A. I., Evtifeeva, O. A., Proskurina, K. I., \& Bezumova, O. V. (2014). Standartizovannaya protsedura validatsii spektrofotometricheskikh metodik kolichestvennogo opredeleniya lekarstvennykh sredstv v variante metoda pokazatelya pogloshcheniya. Soobshchenie 1 [A standardized validation procedure of the spectrophotometric method for the quantitative determination of drugs in a variant of the absorption index method. Report 1]. Farmakom, (1), 29-39. [in Russian].

[3] Chonka, H. (2019). The problem of the spread diseases of oral mucosa and treatment options. The 23d International Medical Congress of Students and Young Scientists (p. 234). UKRMEDKNYHA. http:/l dspace.zsmu.edu.ua/bitstream/123456789/11410/1/Chonka234.pdf

[4] Georgievskii, V. P. (Ed.). (2011). Analiticheskaya khimiya v sozdanii, standartizatsii i kontrole kachestva lekarstvennykh sredstv [Analytical chemistry in the discovery, standardization and quality control of medicines] (Vol. 1). NTMT. [in Russian].

[5] Verkhovna Rada of Ukraine. (1996, April 04). Zakon Ukrainy «Pro likarski zasoby» [Law of Ukraine "On Medicinal Products» (No. 123/96-VR)]. https://zakon.rada.gov.uallaws/show/123/96-\%D0\%B2\%D1\%80\#Text

[6] Danilevskii, N. F, \& Borisenko, A. V. (2000). Zabolevaniya parodonta [Periodontal disease]. Zdorov'e. [in Russian].
[7] Nwizu, N., Wactawski-Wende, J., \& Genco, R. J. (2020). Periodontal disease and cancer: Epidemiologic studies and possible mechanisms. Periodontology 2000, 83(1), 213-233. https://doi.org/10.1111/prd.12329

[8] Kucherenko, L. I., Belenichev, I. F., \& Chonka, O. O. (2019). A study of the antimicrobial and fungicidal activity of a potentially new combined tablet preparation based on decamethoxin and thiotriazolin. Technological and biopharmaceutical aspects of the drug discovery with different mechanisms of action. Proceedings of the International Scientific and Practical Internet Conference (pp. 12-13). Kharkiv. http://dspace.zsmu. edu.ua/handle/123456789/11750

[9] Zubatyuk, R. I., Kucherenko, L. I., Mazur, I. A., Khromyleva, O. V., \& Shishkin, O. V. (2014). A Theoretical Structural Study of Isoniazid Complexes with Thiotriazoline. Chemistry of Heterocyclic Compounds, 50, 438-443 https://doi.org/10.1007/s10593-014-1493-4

[10] Sánchez-Bernal, J., Conejero, C., \& Conejero, R. (2020). Recurrent Aphthous Stomatitis. Aftosis oral recidivante. Actas Dermo-Sifiliograficas, 111(6), 471-480. https://doi.org/10.1016/j.ad.2019.09.004

[11] Sawada, S., Chosa, N., Ishisaki, A., \& Naruishi, K. (2013). Enhancement of gingival inflammation induced by synergism of IL-1 $\beta$ and IL-6. Biomedical Research, 34(1), 31-40. https://doi.org/10.2220/ biomedres.34.31

[12] Mossey, P. A., \& Modell, B. (2012). Epidemiology of Oral Clefts 2012: An International Perspective. In M. T. Cobourne (Ed.), Cleft Lip and Palate. Epidemiology, Aetiology and Treatment (Vol. 16, pp. 1-18). Frontiers of Oral Biology. Basel, Karger. https://doi.org/10.1159/000337464

[13] Kinane, D. F., Stathopoulou, P. G., \& Papapanou, P. N. (2017). Periodontal diseases. Nature Reviews Disease Primers, 3, Article 17038. https://doi.org/10.1038/nrdp.2017.38 